\title{
Análise cultural de produtos audiovisuais: relato de construção de protocolo teórico-metodológico
}

CULTURAL ANALYSIS OF AUDIOVISUAL PRODUCTS: REPORT OF CONSTRUCTION OF THEORETICAL-METHODOLOGICAL PROTOCOL

\section{Márcio Monteiro}

Doutor em Comunicação pela Pontifícia Universidade Católica do Rio Grande do Sul e professor do Departamento de Comunicação Social da UFMA, vinculado ao Observatório de Experiências Expandidas em Comunicação - ObEEC/ UFMA. Pós-doutorando em Comunicação pela Universidade do Vale do Rio dos Sinos. Coordenador do projeto de pesquisa Construção de protocolo teórico-metodológico para análise cultural de produtos audiovisuais.

E-mail: marcio.ufma@gmail.com

\section{Patrícia Azambuja}

Doutora em Psicologia Social pela UERJ, mestre em Artes Visuais pela UNESP e pesquisadora vinculada ao Observatório de Experiências Expandidas em Comunicação - ObEEC/ UFMA. Autora do livro Televisão Hibrida: recepção de TV sob a perspectiva sociotécnica da Teoria Ator-rede, também coordenou o projeto de pesquisa Comunicação Expandida II (Financiado pela FAPEMA).

E-mail: patriciaazambuja@yahoo.com.br

Recebido em 28/07/2018. Aprovado em 02/10/2018.

\section{Resumo}

Relata-se, nesta apresentação, as atividades desenvolvidas no âmbito de um projeto de pesquisa em andamento, coordenado pelo autores, cujo objetivo principal é a elaboração de um modelo de análise aplicada, afinado com a tradição dos estudos culturais em sua relação com o campo da Comunicação. Parte da proposta de análise cultural, delineada por Williams (2003) e Johnson (2010), e se justifica no intuito de compreender as articulações entre o produto audiovisual e suas instâncias de produção e consumo.

Palavras-chave: Estudos Culturais. Análise cultural. Audiovisual.

\section{Abstract}

In this presentation, we describe the activities carried out as part of an on-going research project, coordinated by the authors, whose main objective is the elaboration of an applied analysis model, in tune with the tradition of cultural studies in its relation with the field of Communication. It starts from the draft of cultural analysis, delineated by Williams (2003) and Johnson (2010), and is justified with the aim to understand the articulations between the audiovisual product and its instances of production and consumption.

Keywords: Cultural Studies. Cultural analysis. Audiovisual. 


\section{Tema central e objetivo}

Em maio de 2018, um vídeo circulou como um viral pela internet. This is Ameri$c a^{1}$, rap produzido por Childish Gambino (pseudônimo musical do ator e produtor Donald Glover), com videoclipe dirigido por Niro Murai, não apenas alcançou mais de 260 milhões de visualizações no Youtube em um mês, como movimentou esforços significativos de fãs, especialistas e da mídia no sentido de decifrar as referências utilizadas pelo artista.

O mais curioso talvez não seja apenas os significados implícitos na obra, mas a motivação para tanta atenção em torno de um único trabalho. Alonso (2018, s/p) afirmou ser muito arriscado analisar o vídeo de fora das fronteiras dos Estados Unidos "onde $39 \%$ das pessoas mortas pela polícia são negras, mesmo que representem apenas $13 \%$ da população". Ele apontou teorias que se propagaram a questionar o racismo, a violência desmedida contra negros, o armamento, a indústria midiática do espetáculo, a si próprio como pretensa proposta de mudança, enfim. De acordo com Alonso (2018, s/p), o debate não é novo: “o videoclipe espetáculo que afirma que o espetáculo faz esquecer o horror que nos rodeia também" é um tipo de denúncia social que já foi feita por muitos anteriormente. Entretanto, o trabalho de Childish Gambino tem o mérito de apontar para inúmeras direções e, entre vítimas e algozes, Alonso (2018, s/p) cita como aspecto a destacar o termo zeitgeist, que significa "clima cultural e moral de uma época", a incluir os que estão fora da cena, que recebe sem filtro e em alta definição alguns fatos polêmicos que ainda acontecem nos EUA.

Entre possibilidades a fundamentar-se através da iconologia ou da semiótica, gostaríamos de propor, considerando aspectos desse exemplo em específico, uma abordagem na qual a produção audiovisual não esteja apartada da ideia de cultura como registro dos modos de vida (WILLIAMS, 2003).

Neste artigo, apresentamos discussão vinculada a um projeto de pesquisa, coordenado pelos autores, cujo objetivo central é a organização de um protocolo teórico-metodológico que permita, a partir do materialismo cultural de Williams $(2003,2011)$ e do circuito cultural de Johnson (2010), o estabelecimento de análises culturais que levem em conta, ao mesmo tempo, a dimensão política, econômica e a articulação entre produção e consumo de produtos audiovisuais.

Por meio deste relato, buscamos explicitar os objetivos do referido projeto de pesquisa, discutir algumas questões teóricas fundamentais e argumentar em defesa de um

1. Disponível no link: https://www.youtube.com/watch?v=VYOjWnS4cMY. 
procedimento mais orgânico para a análise de produtos audiovisuais. $\mathrm{O}$ artigo apresenta ainda, com base na discussão proposta por Moraes (2016), o materialismo cultural como um método coerente em relação aos princípios que norteiam os estudos culturais.

\section{Caracterização do estudo}

Williams (2003), um dos principais nomes associados à fundação dos estudos culturais, propôs que a definição de cultura seja constituída a partir de três categorias gerais (frequentemente tratadas como distintas): a "ideal", a "documental" e a "social". De fato, cada uma das categorias privilegia um aspecto diferente das demais e demanda procedimentos específicos no exercício de análise. A categoria “ideal”, por exemplo, pensa a cultura relacionada a um processo de aperfeiçoamento humano. A análise da cultura que aceita essa definição precisaria necessariamente descobrir e descrever quais são os valores atemporais que fazem referência à condição humana universal. Para a categoria "documental", cultura é um corpo de obras intelectuais e imaginativas nas quais encontram-se registrados os pensamentos e as experiências humanas. A análise que coaduna com essa perspectiva é crítica e está fundamentada na descrição e reflexão sobre a natureza e as formas que tomam a experiência e o pensamento do homem. Importa, nesse sentido, "descobrir 'o melhor do que tem sido pensado e escrito no mundo"” (WILLIAMS, 2003, p. 51, tradução nossa). A terceira categoria apresenta uma definição "social” de cultura, por meio da qual esta é compreendida como uma descrição de um modo particular de vida. Essa descrição teria a capacidade de expressar certos sentidos e valores não apenas na arte e nos processos de aprendizagem, mas também nas instituições e no comportamento cotidiano comum. Analisar a cultura a partir dessa última definição implica em esclarecer os sentidos e valores implícitos e explícitos em um modo de vida particular, em uma cultura particular.

O método designado por materialismo cultural decorre dessa compreensão. Para Cevasco (2016), a redefinição de cultura proposta por Williams (2003) era também uma redefinição da política cultural que tinha, de modo geral, o objetivo de difundir os produtos da alta cultura entre todas as classes sociais. A noção expandida de cultura precisava, em contrapartida, incluir os significados e valores que organizam a vida comum, ou seja, a cultura deveria ser pensada como parte constitutiva da vida concreta e não como uma instância separada. Tornou-se impossível, a partir desse movimento, separar questões culturais de questões políticas e econômicas. 
A análise cultural, que na perspectiva de Moraes (2016) é um método de procedimentos de pesquisa ligado ao materialismo cultural, possui três características gerais: é política; é conjuntural; e articula produção e consumo. Por ser política e conjuntural, o estudo deve incluir necessariamente questões contemporâneas de ordem política e econômica, bem como os diversos eventos e acontecimentos - especificamente localizados -, que implicam os processos sob investigação. A esse respeito, Moraes (2016, p. 33) aponta que:

[...] os padrões que marcam as práticas sociais num específico momento e numa particular formação social e as maneiras como são vividos, experimentados e, por vezes, reinventados pelos sujeitos, de modo a se tornarem "novas práticas sociais", constituem seus "modos de organização", ou seja, "padrões culturais", de onde as regularidades e as rupturas podem ser rastreadas no processo analítico, tendo em conta, para tanto, os elementos que são capazes de diagnosticar essas conjunturas espaçotemporais e, nelas, a experiência dos sujeitos.

Por meio do circuito da cultura (JOHNSON, 2010), produtos e processos culturais são mais bem compreendidos quando analisados a partir de um modelo não fragmentado e, portanto, mais complexo. Embora seja distinto dos demais, cada momento depende dos outros e é indispensável para o todo. Os quatro momentos do circuito são: 1) produção; 2) textos; 3) leituras; e 4) culturas vividas. Nesse sentido, se os produtos audiovisuais são essencialmente mercadorias, a produção e o consumo são implicados por condições capitalistas de produção e consumo. Ambos estão articulados às culturas vividas que, por sua vez, são implicadas pelas relações sociais. Para que seja efetivamente considerada conjuntural, a análise precisa necessariamente levar em conta todos esses fatores cotidianos, contemporâneos, que implicam os demais momentos do processo.

O que Johnson (2010) parece tentar demonstrar com o circuito da cultura, a partir das conexões entre os momentos que o compõem, é que fatores internos e externos, objetivos e subjetivos - implicados em processos e práticas culturais - mantém relação de complementaridade e reciprocidade: fatores internos entendidos como aqueles relacionados ao texto e fatores externos, contextuais, como campo de tensões e disputas no que diz respeito ao sentido.

De modo a melhor discutir cada momento do circuito na sua relação com os demais, os dados precisam ser coletados e analisados a partir do que Johnson, Chambers, Raghuram e Tincknell (2004) propõem como uma combinação de metodologias. O obje- 
tivo do projeto de pesquisa aplicada em andamento é, dessa forma, orientar a realização de análises culturais de produtos audiovisuais a partir dessa combinação. É importante reiterar que a pesquisa está em andamento e que as possibilidades de abordagem ainda estão sendo discutidas considerando os problemas de pesquisa definidos. Assim que as técnicas de coleta de dados a serem utilizadas para a aproximação com cada momento do circuito é um aspecto a ser definido em momento posterior.

\section{Sobre os textos}

Para Hall (2016, p 17), a linguagem é "o meio privilegiado pelo qual 'damos sentido' às coisas". Para ele, as diferentes formas de produção são consideradas tal qual línguas pelo simples fato que são "sistemas de representação [...] utilizam algum componente para representar ou dar sentido àquilo que queremos dizer e para expressar ou transmitir um pensamento, um conceito, uma ideia, um sentimento" (HALL, 2016, p. 23). $\mathrm{O}$ ato de representar - "processo pelo qual institui-se um representante que, em certo contexto limitado, tomará o lugar do que representa" (AUMONT, 1993, p. 101) - envolve linguagem, signos e imagens, o que por outro lado está longe de ser um processo simples.

Compartilhamos códigos, conceitos e sentidos que traduzem diferentes linguagens (ou sistemas de representação da cultura). Portanto, os processos de significação são codificados (e interpretados) através diversas estratégias conceituais e técnicas. Tomando como exemplo a imagem, Aumont (1993, p. 14) afirma tratar-se de uma discussão ambiciosa, pois busca atender à diversidade de atividades humanas. Logo, para discutir a complexidade do audiovisual contemporâneo, passamos a perceber "o sentimento generalizado de se viver em um mundo onde as imagens são cada vez mais numerosas, mas também cada vez mais diversificadas e mais intercambiáveis". Pela mesma razão, sempre buscamos analisar o audiovisual incluindo, neste debate, um aglomerado de atravessamentos possíveis e influências diversas.

A análise fílmica teve início com a linguagem cinematográfica e ampliou-se através do potencial expressivo da imagem em movimento, que passa a transitar por diferentes meios e, consequentemente, incorporar diversos "paradigmas de interpretação" (HALL, 2016, p. 21). Em comum, tanto o filme em particular, como o audiovisual no geral, fundamentam-se em uma base textual que, neste caso, produz significado por sua estrutura narrativa (com dados narratológicos, visuais e sonoros), e tem como fim estabelecer efeitos no espectador: "nós concedemos sentido às coisas pela maneira como as 
representamos - as palavras que usamos para nos referir a elas, as histórias que narramos a seu respeito, as imagens que delas criamos, as emoções que associamos a elas, as maneiras como as classificamos e conceituamos, enfim, os valores que nelas embutimos" (HALL, 2016, p. 21).

Portanto, a fotografia em ação - com áudio e imagem simultâneos - que se consolida com o cinema observa requisitos básicos, entre fatores dramático-narrativos, estéticos, psicossociais, técnicos, entre outros. Aos requisitos narrativos está incorporada a capacidade de estruturar os valores da história e fazer o público se envolver com os personagens e conflitos ali retratados. As bases estão na linguística e na ideia de narrativa como o modo de relatar fatos e encadear ações dramáticas (TODOROV, 2003).

Somado a esse conjunto, os requisitos técnicos materializam especificidades à narrativa. Trata-se de como a linguagem se estabelece através de determinada tecnologia operacional, e as lógicas de enunciação visual desses aparelhos. Diz respeito também às etapas de produção e modos de percepção do audiovisual em diferentes meios e gêneros: cinematográficos (AUMONT, 1995; EISENSTEIN, 2002), televisivos (MACHADO, 2005) e convergentes (JENKINS, GREEN, FORD, 2014; MITTELL, 2015).

Convém mencionarmos o papel que o som desempenha nesse encadeamento, reforçando a dimensão narrativa por meio da narração, dos diálogos, de ruídos que marcam ações e movimentos e, também, da música diegética. Conforme pontua Rodríguez (2006), além de conduzir a interpretação do conjunto audiovisual e transmitir sensações espaciais, o áudio atua organizando narrativamente o fluxo do discurso. Convoca-se, nesse sentido, a atenção para a cultura audiovisual, em contraposição à ideia de uma mídia visual ligada exclusivamente à imagens tecnicamente puras. Condições de produção e de leitura articulam-se, desse modo, em função de uma outra articulação: aquela que acontece entre o som e a imagem. "O som não enriquece imagens, mas modifica a percepção global do receptor [...] fornecendo informações que o receptor processará de modo complementar em função de sua tendência natural à coerência perceptiva" (RODRÍGUEZ, 2006, p. 277).

Os requisitos estéticos não apenas englobam o sentido de ser agradável ao olhar, mas sobretudo de estabelecer estratégias expressivas, que tocam os sentidos e as emoções mais profundas. São reflexões que partem do campo da arte e da expressão humana, avaliadas em suas dimensões visuais, visíveis, de representação e ilusão, descritas entre outros por Aumont et al. (1993), Gombrich (1995), Arnheim (1995); ou das alterações psico cognitivas do olhar, em Benjamin (1994) e Crary (2012). 
Hall (2016), ainda sobre representação, sugere dois direcionamentos: 1) o que produz semelhança em nossos sentidos, e 2) o que põe-se no lugar de outra coisa, simboliza algo para além do apresentado. "O sentido depende da relação entre as coisa no mundo - pessoas, objetos e eventos, reais ou ficcionais - e do sistema conceitual, que pode funcionar como representante mental delas" (HALL 2016, p. 36). Para os estruturalistas, o mundo material passa a existir a partir da dimensão simbólica do sistema de linguagem e seus significados. Em contrapartida, a dimensão artística instiui-se para além das condições arbitrárias determinadas pelos símbolos socialmente aceitos: sua simbologia reside no universo dos sentimentos, com poder de ampliar os limites para o uso da linguagem.

Aumont (1993, p. 123-259) avalia o componente emocional vinculado à experiência de representação, no cinema, como estando vinculado "às estruturas narrativo-diegéticas" e, em relação à imagem artística de forma geral, ainda pouco explorado, mas com poder de "inventividade nitidamente superior à de qualquer outra".

As imagens que compartilhamos podem nos ajudar a compreender o mundo em que vivemos, e os produtos audiovisuais, como bases materiais deste mundo, produzem significados e diferentes efeitos ao incorporar uma gama complexa de influências, tanto no que diz respeito aos processos de produção quanto em relação à crítica e à análise. Da percepção ao reconhecimento, passando pela interpretação, o trabalho analítico utiliza-se de abordagens diversas: são tanto iconológicas, de propriedade histórica para as ações das imagens (PANOFSKY, 1986); quanto semiológicas ou semióticas (SAUSSURE, 2012; BARTHES, 1999; JOLY, 1996), com abordagem ligada ao funcionamento geral dos veículos da linguagem; como discursivas (FOUCAULT, 2008), centradas na função geral do conjunto de ideias, imagens ou práticas. "Uma diferença fundamental é que a abordagem semiótica se concentra em como a representação e a linguagem produzem sentido [...] enquanto a abordagem discursiva se concentra mais nos efeitos e consequências da representação - isto é sua 'política"” (HALL, 2016, p. 26-27).

Embora reconheçamos a existência de propostas consolidadas com campo do estudo da linguagem imagética, há a urgência em organizarmos as ideias postas sobre análises fílmicas para darmos conta de produtos audiovisuais a partir do que Hall (2016, p. 27) definiu como "virada discursiva' nas ciências humanas e sociais”, que marca o pós-estruturalismo. Compreendemos ser necessária uma maior especificidade em relação às dimensões internas e externas dos produtos a serem investigados. Isso inclui levar em consideração: tanto as produções em si, como os modelos de negócio; os gêneros e formatos diversos; movimentos culturais que têm influenciado a constituição da linguagem 
audiovisual; práticas midiáticas que fazem mediação entre a indústria e os consumidores; aspectos relacionados a disputas de poder; e possibilidades cada vez mais particulatizadas de consumo e de atribuição de sentido.

De acordo com Mitchell (1995), o campo dos visual studies busca atender à complexidade dos processos contemporâneos de comunicação visual e, em certo sentido, equalizar o embate entre o poder da imagem e as múltiplas funcionalidades promovidas pela tecnologia. São muitos os estudos preocupados com o funcionamento dos mecanismos de mediação técnica, entretanto, os consequentes desdobramentos das experiências visuais não parecem apartados de seu contexto.

Partindo da ideia de percepção materialista da cultura, consideramos o alerta feito por Cevasco (2003), para quem os bens culturais são, também, resultado dos meios materiais de produção - que abrangem da linguagem aos dispositivos eletrônicos de comunicação. Assim constata-se as "viradas" também no sentido de entender que as obras precisam operar para além da dialética tradicional entre significante e significado, ou como objetos acabados e fixos (FISCHER-LICHTE, 2011). Do mesmo modo como a cultura, os processos de comunicação em geral e o audiovisual em específico estão vivos e operam em múltiplas dimensões. Investe-se, portanto, às ferramentas metodológicas a ação dar conta dessas transformações, observar os processos não apenas em sua abordagem intelectual, mas vinculados aos aspectos de vivências particulares, no âmbito das experiências, das emoções, do afeto, da fisiologia, entre outras.

Mitchell (2003) inclusive nos lembra do nosso próprio ato de olhar como uma prática cultural construída "que es aprendida y cultivada, no simplemente dada por la naturaleza" (MITCHELL, 2003, p. 19). Um processo que pode (e precisa) alimentar diferenes regimes de visualidades, "otras modalidades sensoriales como el oir e el tocar" (MITCHELL, 2003, p. 28), enfraquecendo o que chamou de "hegemonia do visível" (MITCHELL, 2003, p. 28).

Já Fabris (1998, p. 1) coloca a questão sobre o que seria a imagem. Para a autora, vivemos mudanças nas formas de pensamento e a contingência de reinvenção imagética: a "coexistência de diferentes tipos de imagem não permite mais conceder primazia à representação, [as abstrações formais estão] tomando cada vez mais o lugar da imagem especular, marcando a passagem da natureza para a linguagem e redefinindo o regime da visualidade contemporânea".

Nas seções seguintes, seguindo a proposição de descentramento do texto (JOHNSON, 2010) no processo de análise cultural, pontuamos a necessidade de compreensão 
do que acontece, em termos de rotinas, modos e práticas, nos âmbitos da produção e do consumo audiovisual.

\section{Sobre as condições de produção: regimes visualidade e poder}

Johnson (2010), refletindo sobre a influência do marxismo nos estudos culturais, reforça a posição do materialismo cultural. Primeiro, reitera que os processos culturais estão intimamente vinculados às relações sociais. Depois, que cultura envolve poder. Por último, que a cultura não é um campo autônomo, nem externamente determinado, mas um local de diferenças e lutas sociais. Os estudos culturais, por essa perspectiva, dizem respeito ao "esforço para retirar o estudo da cultura do domínio pouco igualitário e democrático das formas de julgamento e avaliação que, plantadas no terreno da 'alta' cultura, lançam um olhar de condescendência para a não cultura das massas”(JOHNSON, 2010, p. 20).

Apesar de Hall (2016, p. 48) afirmar que a "linguagem nunca pode ser um jogo inteiramente privado" e nossos sentidos, ainda que pessoais, tenham "de entrar nas regras, códigos e convenções da linguagem para serem compartilhado e entendidos", ele também argumenta que as linguagens têm poder de usar signos para diferentes fins e não "existe um simples relação de reflexo, imitação ou correspondência direta entre a linguagem e o mundo real" (HALL, 2016, p. 53). Logo, a construção desse mundo depende de abordagens diferenciadas, que funcionam em níveis distintos de interpretação (tanto históricos, como linguísticos e culturais). Compreende-se, dessa forma, a existência de múltiplas estratégias para a representações, nem sempre reveladas a priori.

Hall (2016, p. 78) alerta para o fato de que se a linguagem fala de nós “[...] também é importante notar que em certos momentos históricos algumas pessoas têm mais poder para falar sobre determinados assuntos do que outras", portanto, podemos reconhecer de antemão "modelos de representação", alguns com mais visibilidade e aceitos que outros. No intuito de compreender tais práticas, destaca-se a abordagem discursiva das formas de representação cultural, desenvolvida por Foucault (2008), para quem o foco não é o sentido apenas (como no entendimento linguístico da semiótica), mas o conhecimento, o discurso e as relações de poder estabelecidas por esses regimes de visibilidade, assim como, suas especificidades históricas.

"O conceito de discurso não é sobre se as coisas existem, mas sobre de onde vem o sentido das coisas" (HALL, 2016, p. 81). Com esta afirmação retomamos o 
exemplo apresentado no início deste artigo, o clipe produzido para o rap This is America, no qual essas várias camadas de representação podem ser observadas. A apresentação tecnicamente fiel (às vezes extremamente acentuada) de posturas corporais, expressões faciais, comportamentos, práticas com alguns objetos, entre eles armas e aparelho celulares, assim como, a violência explícita, em quase todos os momentos, sugerem o que os semióticos chamam de significados mais amplos, que buscam amparo nos quadros conceituais de determinada cultura, para que então possamos compreender os aspectos particulares das imagens apresentados, tais como: personagens históricos daquele país, movimentos de danças ancestrais e contemporâneas, contexto da história recente, tradições musicais somadas a aparatos de segregação racial e de disputas civis em favor da escravidão. São estes alguns aspectos decodificados através dos "paradigmas de interpretação" (HALL, 2016, p. 21) e suscitados pela estrutura imagética do videoclipe.

Mas se buscássemos, além do sentido "estável" proposto pela linguagem audiovisual, um entendimento social vinculado às questões de cultura e poder, do que Childish Gambino poderia estar realmente tratando? Estaria apenas trazendo à tona imagens icônicas e aspectos da cultura norte-americana? Discutindo sobre a violência que atinge especialmente negros EUA?

Se o "sentido" (semiótico) vinculando imagens de violência à população negra deixa explícito um problema social, também aparece no "conhecimento" sobre as condições de produção o "discurso" acerca do poder que a indústria do entretenimento exerce sobre o seu público. Donald Glover concedeu muitas entrevistas, antes mesmo da produção do vídeo, sugerindo o seu objetivo em ter poder, para assim conseguir fazer escolhas próprias e dar visibilidade às questões que considerava relevantes. Portanto, se o seu poder hoje é evidente, e a política de produção norte-americana está na contramão dos seus interesses, podemos concluir que o artista buscou com o clipe propor novos "paradigmas de interpretação", e assim alterar "mapas conceituais" e regimes de visibilidade?

Nesse caso específico, a coleta documental - reportagens, filmes, fotografias, diários, cartas, relatórios, tabelas estatísticas ou documentos oficiais - é essencial para o estabelecimento da argumentação sobre as condições de produção. Parte do trabalho do analista, então, seria fazer um levantamento detalhado do que, por exemplo, foi dito a respeito do produto tanto por quem trabalhou nele diretamente quanto por quem conhece os produtores, assim como, os contextos específicos da produção. 


\section{Sobre as culturas vividas: registro de modos de vida}

Por outro lado, outras questões surgem, tais como: de onde vem o sentido dado às imagens criadas por Gambino? Ou: quanto sobre nossas práticas sociais (ou deles) está representado ali?

"[Foucault] defendeu que, em cada período, o discurso produz formas de conhecimento, objetos, sujeitos e práticas de conhecimento que são radicalmente diferentes de uma época para outra, sem uma necessária continuidade entre elas" (HALL, 2016, p. 84), portanto, as representações minuciosamente planejadas para o vídeo, em nosso contexto histórico específico e nas suas correlações à vida profissional de Donald Glover, certamente querem dizer mais. Aspectos de segregação ou apropriação cultural indevidas operam, por exemplo, em dimensões similares nos EUA e no Brasil? A distração produzida pela indústria do entretenimento trata de conceitos universalmente assimilados? A partir de quais parâmetros as referências e os sentidos estão estruturados?

Para Hall (2016, p. 86), a relação entre discurso, conhecimento e poder marcou o paradigma da representação pautado em uma estrutura fechada "puramente formal e deu a ela um contexto operacional histórico, prático e 'global'", conectada de maneira mais íntima às práticas sociais e às questões de poder. A noção de representação assume portanto seu papel político e

[...] em seu ato de representar, constitui não somente a identidade, mas a própria qualidade existencial, ou "realidade" (ontologia), da comunidade política, sendo representada em seus valores, interesses, posicionamentos, prioridades, com seus membros (e não membros), suas regras e instituições. Nesse contexto, da "representação como política", não ter voz ou não se ver representado pode significar nada menos que opressão existencial (HALL, 2016, p. 13).

Ao considerarmos eventos midiatizados, percebe-se de imediato o envolvido de codificações específicas. Fiske (2011, p. 4), em Television Culture, define alguns códigos vinculados à televisão. Para ele, o código é um sistema de signos regidos por regras, usado para gerar e fazer circular significados "em e para" determinada cultura. São conexões entre produtores, textos e audiência, isto é, agentes de intertextualidades em uma rede de significados que se relacionam por diferente níveis: 1) realidade, 2) representação e 3) ideologia. 
Como já discutido na parte inicial deste texto, os códigos de realismo que envolvem a aparência, o ambiente, os comportamentos e os sons são convertidos em dados técnicos (câmera, luz, edição, áudio etc.) em nível representacional (narrativa, personagem, elenco, ambientação, conflito, ação etc.), no entanto, não se esgotam assim, pois são organizados retoricamente com pretensões à aceitação, por isso, são mediados por códigos ideológicos (individualismo, liberdade, capitalismo, materialismo, raça, classe, patriarcado, entre outros).

Williams (2003, p. 52), como já demonstrado, discorre sobre a definição social da cultura, como um modo determinado de vida, uma conjuntura. A análise cultural trata, de forma implícita e explícita, dos entendimentos acerca dos modos específicos do cotidiano. A análise cultural pressupõe a polissemia do campo, que no envolvimento com a audiência sugere um lugar de lutas por sentidos.

Por outro lado, segundo Rocha (2011, p. 9), os textos não são absolutamente hegemônicos, pois sua estrutura depreende diversidade de sentidos, e precisam dar conta de uma mediação entre instância produtora e audiência. "Nenhum texto é puramente associativo ou lógico. Todos contêm ambos os princípios e a tensão entre eles é parte da luta textual entre fechamento e abertura, entre dominação e resistência". Por essa razão, a ideia de virada nos estudos de recepção é importante, porque passa a aceitar o texto como "potencial de sentidos capazes de serem vistos a partir de uma variedade de modos de atenção e por uma variedade de espectadores" (ROCHA, 2011, p. 8), influenciados não mais apenas pelos modos como os filmes "endereçavam" seu discurso, privilegiando determinadas posições ideológicas, mas pelo número incontável de possibilidades da experiência cultural do humano no mundo.

\section{Sobre a relação entre produção e consumo: principais ferramentas}

A análise cultural se caracteriza por articular os momentos da produção e do consumo. Moraes (2016, p. 34) aponta que essa articulação, no âmbito das pesquisas em Comunicação, relaciona a esfera produtiva com suas representações midiáticas e também com "as maneiras pelas quais os sujeitos se apropriam das mensagens e delas fazem uso em suas vidas privadas".

Apesar da afirmação de Hall (2016, p. 59) sobre a linguagem não ser um jogo individual, algumas práticas específicas podem alterar sentidos socialmente aceitos. Entre 
significante, significado e processo histórico, há mudanças com poder de transformar o "mapa conceitual da cultura". Para ilustrar, o autor faz referência ao slogan que ficou famoso nos EUA na década de 60, Black is beautiful, a partir do "qual o significante, preto, foi levado a significar o sentido exatamente oposto (significado) às suas associações prévias”. Para a produção de sentido, o leitor é tão importante quanto o escritor.

A partir do modelo proposto por Hall na década de 1970, que, conforme pontua Escosteguy (1998), apostava na pluralidade dos modos de recepção dos programas televisivos, a análise semiótica e as abordagens etnográficas passaram a compor conjuntamente um tipo particular de análise cultural (ROCHA, 2011). Mais do que buscar compreender as diversas possibilidades de leitura dos textos midiáticos na relação com o sentido preferido pela instância produtora, pretendia-se investigar apropriações, usos, práticas cotidianas implicadas pela mídia. Morley (1996) e Fiske (2011) são nomes importantes na pesquisa sobre recepção televisiva pela condução de estudos empíricos que evidenciavam a produção de sentido por parte das audiências. O que talvez careça de maior reflexão por parte dos pesquisadores ligados à tradição dos estudos culturais é se a ênfase exagerada no momento da recepção não significou, muitas vezes, um certo retorno à compartimentalização dos estudos em função dos componentes de um modelo matemático da comunicação.

A necessidade de uma compreensão mais orgânica dos processos e práticas culturais, na articulação entre os momentos da produção e da recepção com foco nas pesquisas em Comunicação, foi debatida por Escosteguy (2009) em outra oportunidade. Ao discutir protocolos analíticos afinados com a terceira característica da análise cultural, a autora pontua que uma das contribuições do circuito cultural está na possibilidade de construir um objeto de estudo que perceba a cultura como parte das práticas sociais. A pesquisa, nesse sentido, seria "norteada pelo entendimento de como os processos culturais se tornam efetivos na articulação de um todo social" (ESCOSTEGUY, 2009, p. 11).

A abordagem etnográfica, realizada a partir de um viés comunicacional, é uma das possibilidades de coleta de dados que contribui tanto com a compreensão das práticas de produção e consumo, como de suas condições e, ainda, das culturas vividas na articulação com as relações sociais. Permite ao pesquisador identificar, por exemplo, rotinas produtivas, modos de consumo de produtos audiovisuais, sentidos produzidos pela audiência, apropriações e ressignificações cotidianas, além de práticas culturais que implicam processos de codificação e decodificação. O pesquisador precisa, então, prever por quanto tempo realizará a pesquisa de campo, que deve incluir observação 
participante e sistemática, realização de entrevistas não diretivas e descrição densa (GEERTZ, 1989; GUBER, 2016).

A definição de quais técnicas de coleta de dados será utilizada pelos pesquisadores ligados ao projeto de pesquisa depende, conforme já mencionado, da questão de cada proposta analítica. Sabe-se, porém, que a combinação de procedimentos é fundamental, uma vez que a articulação entre produção, texto, consumo e relações sociais subjacentes ao processo depende de que cada momento seja pormenorizado a seu tempo e em função de suas particularidades.

\section{Principais reflexões e conclusões}

Ao partir da perspectiva descrita por Williams (2003) e reiterada por Cevasco (2016), Moraes (2016), Johnson (2010) e Escosteguy (2009), buscamos perceber os processos de produção audiovisual como processos políticos profundamente ligados às experiências cotidianas da sociedade como um todo. O circuito cultural opera no sentido de propor para o audiovisual - seja cinematográfico, autoral ou comercial, seja televisionado ou compartilhado pela Internet - um conjunto de procedimentos metodológicos capazes de dar conta de uma realidade de produção de fato complexa, envolvida com as diferenças e suas múltiplas influências: textos, condições de produção, culturas vividas e recepção. Portanto, os textos não fariam parte de uma estrutura narrativa pré-definida que antecede as experiências sociais, mas é atravessado por elas, sendo o lugar a partir do qual se alimenta e para o qual retorna em forma de repertório.

Nesse sentido, destaca-se a relevância dessas abordagens inclusive para o contexto dos processos de ensino-aprendizagem ou mesmo para o entendimento das visualidades não apenas como recursos técnicos para os profissionais que operam com imagens, mas por suas possibilidades de gerar reflexões, quebra de paradigmas e novos olhares. Trata-se, no fim das contas, de elaborar um protocolo de investigação não exclusivamente acadêmico cujo intuito maior seja o de "ver no presente as sementes do futuro, de novos significados e novos valores que podem anunciar uma nova ordem social" (CEVASCO, 2003, p. 116).

Em relação aos procedimentos de coleta e análise dos dados, é importante observar que pela proposta do circuito da cultura, dentro do que foi chamado de combinação de metodologias, não se cria uma lista fechada de técnicas. Sabe-se que cada momento do circuito é fundamental para que a análise cultural seja dada como concluída, mas é o pes- 
quisador que vai estabelecer, na relação com o objeto de pesquisa, quais as possibilidades e caminhos. O desafio maior, nesse sentido, é tentar não instituir uma nova ortodoxia.

A análise cultural possui, conforme apontado, características que são fundamentais para a compreensão de processos ou produtos culturais. Parte considerável do esforço de professores e alunos ligados a este projeto de pesquisa está em identificar modos de acessar conjuntamente as dimensões político-econômicas, as relações conjunturais e a articulação entre produção e consumo que constituem os produtos audiovisuais. A parte final do trabalho dos analistas é, com base no que foi exposto, identificar, relacionar e interpretar todos esses aspectos como integrados.

A proposta deste artigo é apresentar questões teóricas e metodológicas gerais que norteiam o projeto de pesquisa em andamento. Embora façamos menção a um produto audiovisual específico, o videoclipe de This is America, não tivemos a intenção de apresentar uma análise cultural completa do mesmo. Tal análise, reiteramos, é essencialmente empírica e não encontra lugar nos limites deste artigo. Defendemos, contudo, a apresentação desse percurso no âmbito de uma pesquisa aplicada em andamento por compreendermos que pode produzir, além de críticas e sugestões, novas reformulações.

Entre as dificuldades identificadas até o momento para a realização da análise cultural segundo o modelo do circuito cultural estão: a amplitude dos objetivos específicos, isto é, o volume de trabalho para o levantamento e análise dos dados referentes à produção e ao consumo (bem como dos dados que dizem respeito às suas condições); a complexa análise do texto, que envolve não apenas os códigos nos seus diversos níveis, mas também os sentidos que muitas vezes não são óbvios; o desafio de ler, também como um texto, a realidade concreta dos sujeitos implicados por um determinado circuito cultural; e a já mencionada articulação entre os momentos do circuito e questões conjunturais, de ordem política e econômica, que o rodeiam. Compreendemos, a despeito disso, que a abordagem tem a importante contribuição para a área no sentido de compreender o audiovisual a partir de um enfoque mais amplo, sob um viés comunicativo, a partir da realização de pesquisas empíricas.

\section{Referências}

AUMONT, J. A imagem. Campinas: Papirus, 1983.

AUMONT, J. et al. A estética do filme. Campinas: Papirus, 1995. 
ARNHEIM, R. Arte e percepção humana. São Paulo: Pioneira Editora, 1995.

BARTHES, R. Mitologias. México: Siglo Veintiuno Editores, 1999.

BENJAMIN, W. Magia e técnica, arte e política: ensaios sobre literatura e história da cultura Obras escolhidas. Vol. 1. São Paulo: Brasiliense, 1994.

CEVASCO, M. E. Dez lições sobre Estudos Culturais. 2. ed. São Paulo: Boitempo, 2016.

CRARY, J. Técnicas do observador. Rio de Janeiro: Contraponto, 2012.

ESCOSTEGUY, A. C. Uma introdução aos estudos culturais. Revista Famecos, v. 5, n. 9, p. 8797, 1998.

. Quando a recepção já não alcança: os sentidos circulam entre a produção e a recepção.

E-compós, 12, 1, 1-15, 2009.

EISENSTEIN, S. O sentido do filme. Rio de Janeiro: Zahar Ed., 2002.

FABRIS, A. Redefinindo o Conceito de Imagem. Revista Brasileira de História, v. 18, n. 35, 1998.

FISCHER-LICHTE, E. Estética de lo performativo. Madri: Abada, 2011.

FISKE, J. Television Culture. London: Routledge, 2011.

FOUCAULT, M. A arqueologia do saber. Rio de Janeiro: Forense Universitária, 2008.

GEERTZ, C. A interpretação das culturas. Rio de Janeiro: LTC, 1989.

GOMBRICH, E. H. Arte e Ilusão: um estudo da psicologia da representação humana. São Paulo: Martins Fontes, 1995.

GUBER, R. La etnografia: método, campo y reflexividad. Buenos Aires: Siglo Veintiuno, 2016.

GUILLERMO,A. Por que o violento 'This is America' é o videoclipe do ano (preste atenção no que acontece ao fundo). El País, 2018. Disponível em: <https://brasil.elpais.com/brasil/2018/05/08/ cultura/1525772706_935369.html>. Acesso em: 26 jul. 2018. 
HALL, S. Cultura e representação. Rio de Janeiro: Ed. PUC-Rio, Apicuri, 2016.

JENKINS, H., GREEN, J., FORD, S. Cultura da Conexão: criando valor e significado por meio de mídia propagável. São Paulo: Aleph, 2014.

JOHNSON, R., CHAMBERS, D., RAGHURAM, P., TINCKNELL, E. The practice of cultural studies. Londres: SAGE Publications, 2004.

JOHNSON, R. O que é, afinal, Estudos Culturais. In: SILVA, T. T. da. O que é, afinal, Estudos Culturais? Belo Horizonte: Autêntica, 2010.

JOLY, M. Introdução à análise da imagem. Campinas: Papirus, 1996.

MACHADO, A. A televisão levada a sério. São Paulo: SENAC, 2005.

MACHADO, A.; VÉLEZ, M. L. Questões metodológicas relacionadas com a análise de televisão. E-compós, v. 8, 2007.

MITCHELL, W. J. T. Picture theory. Chicago: University of Chicago Press, 1995.

Mostrando el ver: uma critica de la cultura do visual. Revista Estudios Visuales, v. 1, 2003.

MITTELL, J. Complex TV: the poetics of contemporary television storytelling. New York: NY University Press, 2015.

MORAES, A. L. C. A análise cultural: um método de procedimentos em pesquisas. Questões Transversais, v. 4, n. 7, p. 28-36, 2016.

PANOFSKY, E. Estudos de iconologia. Lisboa: Estampa, 1986.

ROCHA, S. M. A análise cultural da televisão. In: JANOTTI JUNIOR, J.; GOMES, I. M. M., Comunicação e estudos culturais. Salvador: EDUFBA, 2011.

RODRÍGUEZ, A. A dimensão sonora da linguagem audiovisual. São Paulo: Editora Senac, 2006.

SAUSSURE, F. Curso de linguística geral. São Paulo: Cultrix, 2012. 
TODOROV, T. As estruturas narrativas. São Paulo: Perspectiva, 2003.

WILLIAMS, R. La larga revolución. Buenos Aires: Nueva Visión, 2003.

Cultura e materialismo. São Paulo: Unesp, 2011.

$66 \frac{\text { Comunicação \& Inovação, PPGCOM/USCS }}{\text { v.19, n. } 41[49-66] \text { set-dez } 2018}$ 